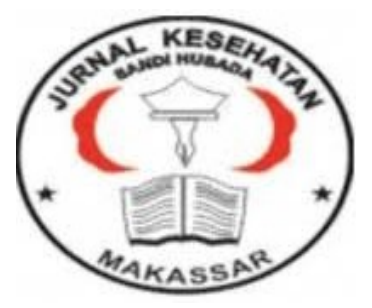

\author{
Jurnal Ilmiah Kesehatan Sandi Husada \\ hhttps://akper-sandikarsa.e-journal.id/JIKSH \\ Vol 11, No, 1, Juni 2020, pp;152-158 \\ p-ISSN: 2354-6093 dan e-ISSN: 2654-4563 \\ DOI: $10.35816 /$ jiskh.v10i2.235
}

\title{
Nilai Indeks Shine dan LAL antara Anemia Defisiensi Besi dengan Thalassemia di RSUD Dr. H. Abdul Moeloek
}

The Value of Shine and LAL Index between Iron Deficiency Anemia and Thalassemia in the Regional General Hospital Dr. H. Abdul Moeloek

\author{
Syuhada1, Zulhafis Mandala², Astri Pinilih ${ }^{3}$, Dwita Canggi Siregar ${ }^{4}$ \\ ${ }^{1}$ Instalasi Unit Transfusi Darah RSUD Dr. H. Abdul Moeloek Provinsi Lampung \\ 2Departemen Biokimia Fakultas Kedokteran Universitas Malahayati \\ ${ }^{3}$ Departemen Anak Rumah Sakit Pertamina Bintang Amin \\ ${ }^{4}$ Program Studi Kedokteran Fakultas Kedokteran Universitas Malahayati
}

\section{Artikel info \\ Artikel history: \\ Received; 16 Maret 2020 \\ Revised:19 Maret 2020 \\ Accepted;21 Maret 2020}

\begin{abstract}
Abstrak
Latar Belakang: Anemia defisiensi besi dan thalassemia $\beta$ minor memiliki gambaran morfologi darah hipokrom yang sama, oleh karena itu perlu dibedakan dengan dilakukannya sebuah pemeriksaan. Diagnosis $\beta$-thalassemia minor dan anemia defisiensi besi dapat ditegakkan dengan melakukan serangkaian pemeriksaan laboratorium skrining, mulai dari pemeriksaan hematologi rutin, sediaan apus darah tepi, pewarnaan sediaan apus darah tepi dengan pewarnaan supravital untuk hitung retikulosit dan deteksi benda inklusi $\mathrm{HbH}$ dalam eritrosit, status cadangan besi darah dengan alur pemeriksaan secara bertahap hingga pemeriksaan yang canggih yaitu elektroforesis $\mathrm{Hb}$ dan pemeriksaan DNA. Tujuan: Untuk mengetahui perbandingan indeks shine \& lal antara pasien anemia defisiensi besi dengan pasien thalassemia di RSUD Dr. H. Abdul Moeloek Provinsi Lampung. Metode: Jenis penelitian ini adalah uji komparatif. Dengan jumlah sampel menggunakan perbandingan 1:1 sehingga didapatkan 45 orang penderita anemia defisiensi besi dan 45 orang penderita thalassemia di RSUD Dr. H. Abdul Moeloek Provinsi Lampung. Hasil: Hasil uji Mann- Whitney menunjukkan nilai sig sebesar 0,029. Maka H1 diterima, karena nilai sig <0,05. Kesimpulan: Terdapat perbedaan bermakna nilai indeks shine \& lal antara pasien anemia defisiensi besi dengan pasien thalassemia di RSUD Dr. $H$. Abdul Moeloek Provinsi Lampung.
\end{abstract}

\section{Abstract}

Background: Iron deficiency anemia and $\beta$ minor 
thalassemia have the same morphological picture of hypochromic blood, therefore it needs to be distinguished from an examination. The diagnosis of $\beta$-thalassemia minor and iron deficiency anemia can be made by conducting a series of screening laboratory tests, ranging from the routine hematological examination, peripheral blood smear preparations, staining of peripheral blood smear preparations with supravital staining for reticulocyte counts and detection of HbH inclusion objects in erythrocytes, reserve status iron blood with a groove examination in stages until a sophisticated examination that is Hb electrophoresis and DNA examination. Objective: To find out the comparison of the shine \& lal index between iron deficiency anemia patients and thalassemia patients in Dr. H. Abdul Moeloek Lampung Province. Method: This type of research is a comparative test. With the number of samples using a ratio of 1: 1 so that 45 people with iron deficiency anemia and 45 people with thalassemia found in Dr. H. Abdul Moeloek Lampung Province. Results: The Mann-Whitney test results showed a sig value of 0.029. Then H1 is accepted because of the value of sig $<0.05$. Conclusion: There is a significant difference in the value of the shine \& lal index between iron deficiency anemia patients and thalassemia patients in Dr. H. Abdul Moeloek Lampung Province..

Keywords:

Levels of $M C V$,

$\mathrm{MCH}$,

Shine dan Lal; index value;
Coresponden author:

Email: dwitacanggi@gmail.com

artikel dengan akses terbuka dibawah lisensi CC BY -4.0

\section{Pendahuluan}

Anemia termasuk penyakit yang sering dijumpai di seluruh dunia, terutama di negara berkembang seperti Indonesia. Kelainan ini merupakan penyebab debilitas kronik yang mempunyai dampak besar pada kesehatan, ekonomi dan kesejahteraan sosial. Diperkirakan lebih dari 30\% penduduk di dunia atau 1,5 miliar orang yang menderita anemia sebagian besar diantaranya tinggal di daerah tropis. Prevalensi anemia secara global sekitar 51\%. Menurut Departemen Kesehatan tahun 2014, prevalensi anemia pada remaja dan usia produktif sebesar 17-18\%. Anemia ialah penurunan kadar hemoglobin, hitung eritrosit, dan hematokrit yang mengakibatkan jumlah eritrosit dan kadar hemoglobin yang beredar tidak dapat memenuhi fungsinya untuk menyediakan oksigen ke seluruh jaringan tubuh. Penyebab terjadinya anemia, yaitu: asupan yang tidak memadai, hilangnya sel darah merah yang di sebabkan oleh trauma, infeksi, perdarahan kronis, menstruasi, dan penurunan atau kelainan pembentukan sel, seperti: hemoglobinopati, thalassemia, sferositosis herediter, dan defisiensi glukosa 6 fosfat dehidrogenase (Lestari et al.,2017).

Besi (Fe) merupakan zat gizi mikro yang sangat diperlukan bagi tubuh. Umumnya zat besi berasal dari sumber pangan nabati (non heme), seperti: kacang-kacangan dan sayursayuran yang mempunyai proporsi absorbsi yang rendah dibandingkan dengan zat besi yang berasal dari sumber pangan hewani (heme), seperti: daging, telur, dan ikan. Menurut World Health Organization (WHO), kekurangan zat besi sebagai salah satu dari sepuluh 
masalah kesehatan yang paling serius. Remaja ialah salah satu kelompok yang rentan terhadap defisiensi zat besi dan dapat mengenai semua kelompok status ekonomi, terutama yang bersosial ekonomi rendah. Menurut Riset Kesehatan Dasar (Riskesdas) yang dilakukan pada tahun 2013 didapatkan bahwa prevalensi anemia defisiensi zat besi pada remaja menurut jenis kelamin, yaitu: pada anak perempuan sekitar 22,7\% dan pada anak laki-laki 12,4\% sedangkan menurut tempat tinggal, yaitu: pedesaan 18,5\% dan perkotaan 17,3\%. Penelitian yang dilakukan oleh Manampiring dengan survei di empat Provinsi (Sumatera Barat, Riau, Bengkulu, dan Lampung) ditemukan bahwa anak usia sekolah termasuk remaja yang menderita anemia sebanyak 45,31\% (Lestari et al.,2017).

Thalassemia ialah sekelompok gangguan sintesis hemoglobin yang diturunkan secara genetik, dan disebabkan oleh defek pada satu atau lebih gen yang bertanggung jawab untuk mensintesis rantai globin pada hemoglobin. Secara klinis, thalassemia dapat diklasifikasikan menjadi thalassemia mayor, thalassemia minor dan thalassemia intermedia. Diperkirakan 7\% dari populasi dunia memiliki gen thalassemia, dimana kasus terbanyak (sekitar 15\%) berada di Asia. Thalassemia terjadi pada sekitar 44 dari 10.000 kelahiran hidup. Thalassemia $\alpha$ dan $\beta$ sering ditemukan pada keturunan Afrika dan Asia Tenggara. Indonesia termasuk dalam kelompok negara yang beresiko tinggi terkena thalassemia dengan prevalensi thalasemia bawaan (karier) sekitar 3-8\%. Menurut hasil Riset Kesehatan Dasar (Riskesdas) tahun 2007, prevalensi nasional thalassemia adalah 1,5\% (berarti 1-2 orang dari 1000 penduduk di lndonesia merupakan penderita thalassemia) (Maharani dan Astuti, 2014).

Anemia defisiensi besi dan thalassemia $\beta$ minor memiliki gambaran morfologi darah hipokrom yang sama, oleh karena itu perlu dibedakan dengan dilakukannya sebuah pemeriksaan. Diagnosis $\beta$-thalassemia minor dan anemia defisiensi besi dapat ditegakkan dengan melakukan serangkaian pemeriksaan laboratorium skrining, mulai dari pemeriksaan hematologi rutin, sediaan apus darah tepi, pewarnaan sediaan apus darah tepi dengan pewarnaan supravital untuk hitung retikulosit dan deteksi benda inklusi $\mathrm{HbH}$ dalam eritrosit, status cadangan besi darah dengan alur pemeriksaan secara bertahap hingga pemeriksaan yang canggih yaitu elektroforesis $\mathrm{Hb}$ dan pemeriksaan DNA (Wirawan, 2011; Imam Budiwiyono, 2016; Weaterhall, 2016).

Bila semua pemeriksaan tersebut dilakukan secara sekaligus, tentu akan membutuhkan biaya yang sangat besar, sehingga para pakar di bidang hematologi mengemukakan, terdapat beberapa indeks eritrosit. Berbagai indeks eritrosit memiliki validitas yang berbeda dalam membedakan $\beta$-thalassemia dengan anemia defisiensi besi. Salah satu indeks eritrosit yang dipakai oleh pakar hematologi adalah indeks shine \& lal dengan alasan murah, praktis dan dapat diperiksa menggunakan peralatan sederhana. Indeks shine \& lal dihitung dengan rumus MCV x MCV x MCH x 0,01, jika hasilnya <1530 maka interpretasinya adalah thalassemia, dan apabila $>1530$ akan diinterpretasikan sebagai anemia defisiensi besi. Mean Corpuscular Volume (MCV) adalah Volume Eritrosit Rata-Rata (VER) yaitu volume rata-rata sebuah eritrosit disebut dengan fentoliter. MCV dapat menunjukan apakah eritrosit normositik (80-95fl), mikrositik (95). Mean Corpuscular Hemoglobin (MCH) adalah Hemoglobin Eritrosit Rata-Rata (HER), yaitu banyaknya hemoglobin per eritrosit disebut dengan pikogram, MCH dapat menunjukan apakah eritrositnya normokrom (27-34 pg), hipokrom (34 pg) (Pratiwi et al.,2018).

Berdasarkan penelitian yang dilakukan oleh (Pratiwi et al.,2018) di RSUD Abdul Wahab Sjahrani Samarinda mereka mendapatkan hasil penghitungan indeks mentzer dan indeks shine \& lal pada 39 pasien pada periode 2014-2016 menunjukkan bahwa sebanyak 31 pasien dapat diinterpretasikan sebagai thalassemia berdasarkan indeks shine \& lal, dan hanya terdapat 3 pasien yang dapat diinterpretasikan sebagai thalassemia berdasarkan 
hasil penghitungan indeks mentzer. Penelitian serupa pernah kota dilakukan di Bandung pada tahun 2013 oleh (Mianto et al.,2013) menemukan bahwa indeks shine \& lal memiliki sensitivitas dan nilai predlksi positif yang lebih baik daripada indeks mentzer. Karena sebagian besar pasien thalassemia pada penelitian indeks shine \& lal dihitung berdasarkan nilai MCV dan MCH, dimana pada thalassemia mayor terjadi penurunan nllai MCV dan MCH yang lebih besar dibandingkan pada anemia defisiensi besi. Semakin rendah nilai MCVdan $\mathrm{MCH}$, maka hasil hitung indeks shine \& lal juga akan semakin rendah dan berada pada nilai $<1530$, sehingga diinterpretasikan sebagai thalassemia (Pratiwi et al.,2018). Sedangkan pada tahun 2012-2013 peneltian yang dilakukan (Maharani \& Astuti, 2014) di Unit Transfusi Darah Daerah (UTDD) PMI di DKI Jakarta dari 138 donor ditemukan 2 orang thalassemia $\alpha, 3$ orang thalassemia $\beta, 3 \mathrm{HbE}, 4$ orang suspek thalassemia $\alpha$, dan ditemukan nilai prediksi positif $25 \%$. Hal ini menunjukkan indeks shine \& lal tidak terlalu spesifik dalam mendeteksi thalassemia $\beta$ karena dapat mendeteksi thalassemia secara keseluruhan dan juga memiliki MCV yang cukup rendah sehingga sedikit MCV turun dapat dikatakan thalassemia $\beta$ (Maharani \& Astuti, 2014). Berdasarkan uraian latar belakang di atas peneliti tertarik untuk melakukan penelitian mengenai "Perbandingan Nilai Indeks Shine \& Lal pada pasien Anemia Defisiensi Besi dengan pasien Thalassemia di RSUD Dr.H. Abdul Moeloek Provinsi Lampung."

\section{Metode}

Jenis penelitian ini adalah uji Komparatif Kuantitatif. Waktu penelitian di mulai pada tanggal 31 Januari 2020 - 08 Februari 2020 bertempat di Laboratorium Patologi Klinik RSUD Dr.H. Abdul Moeloek Provinsi Lampung. Populasi dalam penelitian ini adalah pasien Anemia Defisiensi Besi dan pasien Thalassemia di RSUD Dr.H. Abdul Moeloek Provinsi Lampung. Adapun jumlah populasi dalam penelitian ini adalah pada Anemia Defisiensi Besi sejumlah 51 orang. Penelitian ini menggunakan research design cross-sectional. Teknik sampling yang digunakan dalam penelitian ini adalah purposive sampling, yaitu teknik penentuan sampel dengan jumlah pertimbangan tertentu. Hasil penelitian ini mengambil data usia, nilai MCV,MCH, dan nilai Indeks Shine \& Lal sebagai data numerik. Sedangkan data kategorik adalah jenis kelamin pasien. Selanjutnya disajikan dalam bentuk tabel. Analisis bivariat penelitian ini menggunakan statistik non parametrik digunakan untuk melihat adanya perbedaan variabel sesuai yaitu perbandingan nilai Indeks Shine \& Lal antara pasien anemia defisiensi besi dengan pasien thalassemia. Dalam analisis dilakukan beberapa tahapan antara lain: Uji Normalitas Shapiro-Wilk, lakukan transformasi data, karena hasil uji normalitas salah satu data (nilai sig $<0,05$ ), dilakukan uji Mann-Whitney karena data tetap tidak berdistribusi normal (nilai sig $<0,05$ ), sajikan hasil output SPSS dalam bentuk tabel.

\section{Hasil Dan Pembahasan}

Tabel 1. Analisis Uji Mann -Whitney untuk membedakan nilai Indeks Shine \& Lal antara

Anemia Defisiensi Besi dengan Thalassemia.

Hasil Uji Mann-Whitney $\quad$ Nilai sig (2-tailed)

Indeks Shine \& Lal ADB dengan Thalassemia $\quad 0,029$

Berdasarkan data usia pada dapat diketahui bahwa usia termuda pada pasien anemia defisiensi besi adalah 0 tahun yaitu 10 bulan, 7 bulan, dan 8 bulan yang artinya $<1$ tahun. Dan usia tertua pada data tersebut adalah 64 tahun. 
Hasil menunjukkan bahwa pasien anemia defisiensi besi pada usia 0-20 tahun ada sebanyak 35 orang dari 45 orang. Untuk usia 0-20 tahun bisa disebut sebagai usia produktif dan usia remaja, hal ini sejalan dengan Departemen Kesehatan tahun 2014, prevalensi anemia pada remaja dan usia produktif sebesar 17-18\%. Anemia ialah penurunan kadar hemoglobin, hitung eritrosit, dan hematokrit yang mengakibatkan jumlah eritrosit dan kadar hemoglobin yang beredar tidak dapat memenuhi fungsinya untuk menyediakan oksigen ke seluruh jaringan tubuh. Penyebab terjadinya anemia, yaitu: asupan yang tidak memadai, hilangnya sel darah merah yang di sebabkan oleh trauma, infeksi, perdarahan kronis, menstruasi, dan penurunan atau kelainan pembentukan sel, seperti: hemoglobinopati, thalassemia, sferositosis herediter, dan defisiensi glukosa 6 fosfat dehidrogenase (Lestari et al.,2017).

Menurut World Health Organization (WHO), kekurangan zat besi sebagai salah satu dari sepuluh masalah kesehatan yang paling serius. Remaja ialah salah satu kelompok yang rentan terhadap defisiensi zat besi dan dapat mengenai semua kelompok status ekonomi, terutama yang bersosial ekonomi rendah.

Diketahui bahwa usia termuda pada pasien thalassemia adalah 3 tahun. Dan usia tertua adalah 59 tahun. Berdasarkan data diketahui bahwa pasien thalassemia usia 0-20 tahun berjumlah sebanyak 35 orang dari 45 orang. Sedangkan data tentang nilai MCV pada pasien anemia defisiensi besi yaitu nilai MCV terendah adalah 57 dan nilai MCV tertinggi adalah 93. Berdasarkan data didapatkan nilai MCV pada anemia defisiensi besi 71-90 fL ada sebanyak 35 pasien dari 45 pasien. Diketahui bahwa nilai MCV terendah pada pasien thalassemia adalah 60 dan nilai MCV tertinggi adalah 86. Berdasarkan data diketahui bahwa nilai MCV pada thalassemia 61-80 fL ada sebanyak 37 pasien dari 45 pasien. Diketahui bahwa nilai MCH terendah pada pasien anemia defisiensi besi adalah 16 dan nilai MCH tertinggi adalah 33. Berdasarkan data diketahui bahwa nilai MCH pada anemia defisiensi besi 21-30 pg ada sebanyak 32 pasien dari 45 pasien. Diketahui bahwa nilai MCH terendah pada pasien thalassemia adalah 17 dan nilai $\mathrm{MCH}$ tertinggi adalah 29. Berdasarkan data dapat diketahui bahwa nilai MCH pada thalassemia 21-30 pg ada sebanyak 41 pasien dari 45 pasien.

Diketahui bahwa nilai indeks shine \& lal terendah pada anemia defisiensi besi adalah 584 dan nilai indeks shine \& lal tertinggi adalah 2854. Berdasarkan data diketahui bahwa nilai indeks shine \& lal pada anemia defisiensi besi $>1530$ ada sebanyak 26 pasien dari 45 pasien. Hasil diketahui bahwa nilai indeks shine $\&$ lal terendah pada thalassemia adalah 612 dan nilai indeks shine \& lal tertinggi adalah 14444. Berdasarkan data diketahui bahwa nilai indeks shine \& lal pada thalassemia $<1530$ ada sebanyak 28 pasien dari 45 pasien. Sedangkan berdasarkan data jenis kelamin pada pasien anemia defisiensi besi berjumlah lebih banyak laki-laki dari perempuan yaitu 25:20. Sedangkan jenis kelamin pada pasien thalassemia berjumlah lebih banyak perempuan dari laki-laki yaitu 20:25. Anemia defisiensi besi dan thalassemia $\beta$ minor memiliki gambaran morfologi darah hipokrom yang sama, oleh karena itu perlu dibedakan dengan dilakukannya sebuah pemeriksaan. Diagnosis $\beta$-thalassemia minor dan anemia defisiensi besi dapat ditegakkan dengan melakukan serangkaian pemeriksaan laboratorium skrining, mulai dari pemeriksaan hematologi rutin, sediaan apus darah tepi, pewarnaan sediaan apus darah tepi dengan pewarnaan supravital untuk hitung retikulosit dan deteksi benda inklusi $\mathrm{HbH}$ dalam eritrosit, status cadangan besi darah dengan alur pemeriksaan secara bertahap hingga pemeriksaan yang canggih yaitu elektroforesis $\mathrm{Hb}$ dan pemeriksaan DNA (Wirawan, 2011; Imam Budiwiyono, 2016; Weaterhall, 2016).

Bila semua pemeriksaan tersebut dilakukan dilakukan secara sekaligus, tentu akan membutuhkan biaya yang sangat besar, sehingga para pakar di bidang hematologi 
mengemukakan, terdapat beberapa indeks eritrosit. Berbagai indeks eritrosit memiliki validitas yang berbeda dalam membedakan $\beta$-thalassemia dengan anemia defisiensi besi. Salah satu indeks eritrosit yang dipakai oleh pakar hematologi adalah indeks shine \& lal dengan alasan murah, praktis dan dapat diperiksa menggunakan peralatan sederhana. lndeks shine \& lal dihitung dengan rumus MCV x MCV x MCH x 0,01, jika hasilnya <1530 maka interpretasinya adalah thalassemia, dan apabila $>1530$ akan diinterpretasikan sebagai anemia defisiensi besi. Mean Corpuscular Volume (MCV) adalah Volume Eritrosit Rata-Rata (VER) yaitu volume rata-rata sebuah eritrosit disebut dengan fentoliter. MCV dapat menunjukan apakah eritrosit normositik (80-95fl), mikrositik (95). Mean Corpuscular Hemoglobin (MCH) adalah Hemoglobin Eritrosit Rata-Rata (HER), yaitu banyaknya hemoglobin per eritrosit disebut dengan pikogram, MCH dapat menunjukan apakah eritrositnya normokrom (27-34 pg), hipokrom (34 pg) (Pratiwi et al.,2018).

Berdasarkan nilai laboratorium untuk penyakit anemia defisiensi besi pada penelitian ini didapatkan nilai MCV rentan 51-100 fL yang didominasi nilai 71-80 fL sebanyak 20 pasien. Sedangkan untuk pasien thalassemia didapatkan nilai MCV rentan 51-90 fL yang didominasi nilai 71-80 fL sebanyak 26 pasien. Untuk nilai $\mathrm{MCH}$ pada pasien anemia defisiensi besi didapatkan 11-40 pg yang didominasi nilai 21-30 pg sebanyak 32 pasien. Sementara nilai MCH pada pasien thalassemia didapatkan 11-30 pg yang didominasi nilai 21-30 pg sebanyak 41 pasien. Setelah dihitung dengan Indeks Shine \& Lal didapatkan hasil nilai indeks pada penyakit anemia defisiensi besi yaitu $>1530$ sebanyak 26 dari 45 pasien. Dan pada penyakit thalassemia didapatkan hasil nilai indeks nya yaitu $<1530$ sebanyak 28 dari 45 pasien. Hasil penelitian ini sejalan dengan penelitian (Mianto et al.,2013) yang dilakukan di kota Bandung menemukan bahwa indeks shine \& lal memiliki sensitivitas dan nilai predlksi positif yang lebih baik daripada indeks mentzer. Karena sebagian besar pasien thalassemia pada penelitian indeks shine \& lal dihitung berdasarkan nilai MCV dan $\mathrm{MCH}$, dimana pada thalassemia mayor terjadi penurunan nllai MCV dan $\mathrm{MCH}$ yang lebih besar dibandingkan pada anemia defisiensi besi. Akan tetapi ada perbedaan pada penelitian yang saya lakukan dengan (Mianto et al.,2013) karena saya tidak melakukan uji validitas untuk mengetahui spesifitas dan sensitivitas juga nilai prediksi positif ataupun nilai prediksi negatif. Penelitian saya sejalan karena sama-sama menggunakan sampel pasien $\beta$ - thalassemia mayor.

Berdasarkan analsisis uji Mann-Whitney didapatkan nilai (sig 0,029) yang berarti H1 diterima karena nilai $(\operatorname{sig}<0,05)$. Yang artinya ada perbedaan bermakna nilai Indeks Shine \& Lal antara anemia defisiensi besi dengan thalassemia. Karena pada hasil penelitian ini setelah dihitung menggunakan rumus Indeks Shine \& Lal untuk anemia defisiensi besi didapatkan 26 dari 45 pasien yang nilai indeksnya $>1530$. Sedangkan untuk thalassemia didapatkan 28 dari 45 pasien yang nilai indeksnya $<1530$. Hal ini membuktikan bahwa Indeks Shine \& Lal bisa dipakai sebagai alat skrining untuk mendiagnosis thalassemia.

\section{Simpulan Dan Saran}

Nilai MCV pada anemia defisiensi besi 51-100 fL dengan nilai MCV 71-80 fLyang terbanyak dan nilai MCH pada anemia defisiensi besi 11-40 pg dengan nilai MCH 21-30 yang terbanyak. Nilai MCV pada thalassemia 51-90 fL dengan nilai MCV 71-80 fL yang terbanyak dan nilai MCH pada thalassemia 11-30 pg dengan nilai MCH 21-30 pg yang terbanyak. Nilai MCV pasien thalassemia lebih rendah dari pasien anemia defisiensi besi dan nilai MCH pasien thalassemia lebih rendah dari pasien anemia defisiensi besi. Nilai indeks shine \& lal pada anemia defisiensi besi $>1530$ yang didapatkan sesuai ada 26 pasien. Nilai indeks shine \& lal pada thalassemia $<1530$ yang didapatkan sesuai ada 28 pasien. Hasil uji Mann-Whitney menunjukkan nilai (sig 0,029) yang berarti H1 diterima 
dan dapat disimpulkan bahwa ada perbedaan nilai indeks shine \& lal antara anemia defisiensi besi dan thalassemia.

Bagi Peneliti Selanjutnya Penelitian yang serupa bisa menggunakan sampel yang belum terdiagnosis thalassemia dan anemia defisiensi besi. Agar penelitian ini bisa langsung diterapkan sebagai alat skrining pada kedua penyakit tersebut. Dan penelitian ini bisa dilakukan di unit transfusi darah dan laboratorium patologi klinik rumah sakit. Agar bisa mengetahui pasien sudah transfusi atau belum agar hasilnya lebih akurat. Dan sebelum mengambil data peneliti harus mengetahui kriteria kedua penyakit tersebut. Bagi Institusi Kesehatan Hasil penelitian ini diharapkan dapat digunakan sebagai alternative untuk pemeriksaan dalam mendiagnosis anemia defisiensi besi ataupun thalassemia. Bagi Instansi Pendidikan Hasil penelitian ini diharapkan dapat menambah referensi tentang perbedaan nilai indeks shine \& lal antara pasien anemia defisiensi besi dengan pasien thalassemia. Bagi MasyarakatSemoga indeks shine \& lal bisa digunakan sebagai alat skrining dalam membedakan antara anemia defisiensi besi dengan thalassemia.

\section{Daftar Rujukan}

Atmakusuma, D .2014. Buku Ajar Ilmu Penyakit Dalam. Edisi Keenam. Jilid II.Jakarta Pusat:Interna Publishing

Bakta, I M \& Dharmayuda. T G .2014. Buku Ajar Ilmu Penyakit Dalam. Edisi Keenam Jilid II. Jakarta Pusat:Interna Publishing.

Bakta, I M .2015. Buku Ajar Ilmu Penyakit Dalam. Edisi Keenam. Jilid II. Jakarta Pusat:Interna Publishing.

Gandasoebrata, R.2013.Penuntun Laboratorium Klinis.Jakarta:Dian Rakyat.

Kiswari. 2014. Hematologi dan Transfusi. Jakarta:Erlangga.

Kementrian Kesehatan Republik Indonesia. Riset Kesehatan Dasar (Riskesdas) 2007.

Kementrian Kesehatan Republik Indonesia. Riset Kesehatan Dasar (Riskesdas) 2013.

Lestari, I P, Lipoeto, N I \& Almurdi.2017.Hubungan Konsumsi Zat Besi dengan Kejadian Anemia pada Murid SMP Negeri 27 di Padang. Jurnal Kesehatan Andalas 6(3): 507-508.

Maharani, E A \& Astuti, D. 2014. Penghitungan Indeks Formula Eritrosit pada Uji Saring Thalassemia Minor. Jurnal Ilmu dan Teknologi Kesehatan 2(1):54-58.

Mianto, N A, Sugiarto, C \& Suhendra, A. 2013. Gambaran Validitas Indeks Mentzer dan ndeks Shine \& Lal pada Penderita $\beta$ Thalassemia Mayor. Skripsi.Program Studi Pendidikan Dokter Universitas Kristen Maranatha. Bandung.

Masrizal. 2007.Anemia Defisiensi Besi. Jurnal Kesehatan Masyarakat 2(1):141.

Notoatmodjo, S.2018.Metodologi Penelitian Kesehatan. Jakarta:Rineka Cipta.

NP, R A .2015.Indeks RDW dan Mentzer sebagai Uji Skrining Diagnosis Thalassemia 4(7):7. Skripsi. Program Studi Pendidikan Dokter Universitas Lampung.

Pratiwi, A N \& Sawitri . 2018. Gambaran Kasus Thalassemia Anak di RSUD Abdul Wahab Sjahranie Samarinda Periode 2014-2016. Jurnal Kedokteran Mulawarman 4(1):53-55.

Rubenstein, D, Wayne, D \& Bradley, J .2007. Kedokteran klinis, Edisi Keenam. .Jakarta:360:Erlangga Medical Series.

Wirawan.2011. Evaluasi Teori Model Standar Aplikasi dan Profesi, Contoh Aplikasi Evaluasi. Program: Pengembangan Sumber Daya Manusia Program Nasional. Pemberdayaan Masyarakat (PNPM) Mandiri Perdesaan, Kurikulum. Perpustakaan, dan Buku Tes. Jakarta:Raja Grafindo Persada. 